\title{
IMPLIKASI PERALIHAN KEWENANGAN BIDANG PERIZINAN PERTAMBANGAN UMUM DARI DAERAH KABUPATEN/KOTA KEPADA PROVINSI JAWA BARAT BERDASARKAN UNDANG- UNDANG NOMOR 23 TAHUN 2014 TENTANG PEMERINTAHAN DAERAH DIHUBUNGKAN DENGAN ASAS-ASAS UMUM PEMERINTAHAN YANG BAIK (Studi Kasus Di Kabupaten Purwakarat)
}

\author{
Bambang Widiya Atmoko \\ Mahasiswa Program Studi Magister Ilmu Hukum Pascasarjana UNISBA \\ E-mail: bambang.widi24@gmail.com
}

\begin{abstract}
Abstrak. Pemberlakuan Undang-Undang Nomor 23 Tahun 2014 tentang Pemerintahan Daerah banyak mempreteli kewenangan di Kabupaten/Kota, salah satunya undangundang tersebut tidak lagi memberikan kewenangan kepada Kabupaten/Kota untuk penerbitan izin pertambangan. Tujuan penelitian ini untuk mengetahui dan memahami kewenangan pengelolaan pertambangan dan implementasi kewenangan pengelolaan pertambangan berdasarkan Undang-Undang Nomor 23 Tahun 2014 tentang Pemerintah Daerah. Metode pendekatan yang digunakan dalam penelitian ini adalah yuridis normatif dengan meneliti bahan-bahan hukum primer, sekunder dan tersier yang diperoleh dari studi kepustakaan yang terkait dengan topik yang diteliti, dan kemudian dianalisis menggunakan metode deskriptif kualitatif. Hasil penelitian menunjukan bahwa pengaturan pertambangan berdasarkan Undang Undang-Nomor 23 Tahun 2014, urusan energi dan sumber daya mineral yang ada di Kabupaten/Kota diserahkan seluruhnya kepada pemerintah provinsi, sedangkan di Kabupaten/Kota, tidak ada pemilahan kewenangan baik secara komoditas maupun kriteria yang memberikan peluang melakukan pengaturan kepada pihak Kabupaten/Kota. Implementasi pengelolaan pertambangan di Kabupaten Purwakarta sudah benar sebagaimana diatur dalam berdasarkan Undang-Undang Nomor 4 Tahun 2009, dengan adanya pembagian kewenangan antara pemerintah pusat, pemerintah daerah provinsi, dan pemerintah Kabupaten/Kota. Perizinan menjadi kewenangan pemerintah provinsi menjadi tidak sederhana, jarak yang jauh dengan tata cara proses rumit, pengawasan dan pengendalian tidak terkendali karena menjadi kewenangan pemerintah pusat.
\end{abstract}

\section{Kata kunci: Pengendalian, Kewenangan, Pemerintah Daerah, Pertambangan}

\begin{abstract}
The enactment of Law Number 23 Year 2014 concerning Regional Government has largely stripped-down authority in the District/City, one of which is that the law no longer gives District/City authority to issue mining permits. The purpose of this research is to know and understand the authority of mining management and the implementation of the authority of mining management based on Law Number 23 Year 2014 concerning Regional Government. This study used normative juridical approach by examining primary, secondary, and tertiary legal materials obtained from literature study related to the topic under study and then analyzed using qualitative descriptive method. The result show that mining arrangements based on Law Number 23 Year 2014, matters of energy and mineral resources in the District/City were left entirely to the provincial government, whereas in the District/City, there was no segregation of authority both in terms of commodities and criteria that gave the opportunity to make arrangements to the District/City. The implementation of mining management in Purwakarta District has been
\end{abstract}


correct as regulated under Law Number 4 Year 2009, with the division of authority among central government, provincial regional governments, and district/city governments. Permission becomes not simple, long distances with complicated procedures, uncontrolled supervision and control because it becomes the authority of central government.

\section{Keywords: Control, Authority, Local Government, Mining}

\section{A. PENDAHULUAN}

\section{Latar Belakang Masalah}

Konsep Negara Indonesia seperti dalam Pasal 18 UndangUndang Dasar Negara Republik Indonesia Tahun $1945^{1}$, pelaksanaan otonomi memiliki prinsip demokrasi, otonomi luas dan kewenangan yang luas, keadilan, pembagian kekuasaan, pengaturan kewenangan, dan penghormatan atas hak-hak asli. Dengan demikian itu merupakan salah satu dari asas-asas penyelenggaraan pemerintahan negara yang menekankan adanya pemberian kewenangan oleh negara kepada daerah untuk mengatur dan mengurus kepentingan masyarakat setempat. $^{2}$

\section{Pemerintah daerah diberi} kebebasan untuk mengatur dan

\footnotetext{
1 Undang-Undang Dasar Negara Republik Indonesia Tahun 1945, Pustaka Agung Harapan. Surabaya.

2 Ade Saptono, Hukum dan Kearifan Lokal Revitalisasi Hukum Adat Nusantara, Jakarta: PT. Grasindo, 2010, Hlm. 36.
}

mengurus rumah tangga daerahnya, menetapkan kebijaksanaan sendiri, serta berkewajiban memenuhi pembiayaan keuangan daerah. Dengan berlakukannya otonomi daerah di Indonesia pada Tahun 2001, organisasi publik yang diberi kewenangan oleh Pemerintah Pusat untuk mengatur pemerintahannya sendiri. Dengan demikian diharapkan suatu daerah otonom dapat berkembang sesuai dengan kemampuan sendiri dan tidak bergantung kepada Pemerintah Pusat. Oleh karena itu, daerah otonom harus mempunyai kemampuan sendiri untuk mengurus dan mengatur rumah tangganya sendiri dengan mengandalkan sumber-sumber pendapatan yang dimilikinya. Sumber-sumber pendapatan tersebut meliputi semua kekayaan yang dikuasai oleh daerah dengan batasbatas kewenangan yang ada dan selanjutnya digunakan untuk 
membiayai semua kebutuhan dalam rangka penyelenggaraan rumah tangga daerah tersebut.

Desentralisasi merupakan penyerahan segala urusan, baik pengaturan dalam pembuatan peraturan perundang-undangan, maupun penyelenggaraan pemerintah dari pemerintah pusat kepada pemerintah daerah untuk selanjutnya menjadi urusan rumah tangga sendiri. Dengan demikian daerah perlu diberikan wewenang untuk melaksanakan berbagai urusan pemerintahan sebagai urusan rumah tangganya, serta sekaligus memiliki pendapatan daerah. $^{3}$

Menurut pendapat Jimly Asshiddiqie penyelenggaraan otonomi daerah menekankan pentingnya prinsi-prinsip demokrasi, peningkatan peran serta masyarakat, dan pemerataan keadilan dengan memperhitungkan berbagai aspek yang berkenaan dengan potensi dan keanekaragaman antar daerah. Dalam arti bahwa dalam penyelenggaraan kebijakan otonomi daerah, menyangkut pengalihan

\footnotetext{
${ }^{3}$ Inu Kencana Syafei, Sistem Pemerintahan Indonesia, Jakarta: Rineka Cipta, 2002, HIm. 85-86.
}

kewenangan dari pemerintahan ke kemasyarakat, yang diharapkan dapat tumbuh dan berkembang keprakarsaan dan kemandiriannya dalam iklim demokrasi dewasa ini. ${ }^{4}$

Aspek yang paling penting dalam penyelenggaraan pemerintahan daerah yaitu gubernur. Kedudukan gubernur sangat penting karena gubernur melekat asas dekonsentrasi sebagai perpanjangan pemerintahan pusat di daerah. Asas Dekonsentrasi adalah pelimpahan wewenang pemerintahan oleh pemerintah kepada gubernur dengan memperhatikan prinsip akutanbilitas, efesiensi dan eksternalisasi serta kepentingan strategi nasional dengan kriteria urusan pemerintahan yang menjadi kewenagan daerah Provinsi ${ }^{5}$

Gubernur dalam kedudukannya sebagai wakil pemerintah pusat mempunyai tugas sesuai Pasal 8 ayat (2) penyelenggaraan Urusan Pemerintahan oleh Daerah kabupaten/kota dilaksanakan oleh gubernur sebagai wakil Pemerintah

\footnotetext{
4 Jimly Asshiddiqie, Konstitusi dan Konstitusionalisme Indonesia, Jakarta: Sinar Grafika, 2010. Hlm, 224.

${ }^{5}$ Pasal 13 ayat (1) UU No. 23 Tahun 2014 tentang Pemerintahan Daerah.
} 
Pusat dan Pasal 25 ayat (2) serta Pasal 91 ayat (1) ayat (4) Undangundang Nomor 23 Tahun 2014 tentang Pemerintahan Daerah ${ }^{6}$.

Dengan adanya otonomi daerah terdapat keuntungan bagi pemerintah daerah antara lain : ${ }^{7}$

a) Meningkatkan kualitas dan kuantitas pelayanan publik dalam mencapai kesejahteraan masyarakat.

b) Memberdayakan dan menciptakan ruang bagi masyarakat (publik) untuk berpartisipasi dalam proses pembangunan.

c) Menciptakan efisiensi dan efektivitas pengelolaan sumber daya daerah.

Berdasarkan Undang-Undang Dasar Negara Republik Indonesia Tahun 1945 pada Pasal 18 Ayat (2), disebutkan :

"Pemerintahan daerah provinsi, daerah kabupaten, dan kota mengatur dan mengurus sendiri

${ }_{7}^{6}$ Ibid.

7 Deddy Supriady Bratakusumah dan Dadang Solihin, Otonomi Penyelenggaraan Pemerintahan Daerah, Jakarta: PT. Gramedia Pustaka Utama, 2002, Hlm. 1. urusan pemerintahan menurut asas otonomi dan tugas pembantuan".

Urusan pemerintahan yang diserahkan kepada daerah menjadi urusan rumah tangga daerah. Terhadap urusan pemerintahan yang diserahkan itu, daerah mempunyai kebebasan (vrijheid) untuk mengatur dan mengurus sendiri dengan pengawasan dari pemerintah pusat atau satuan pemerintah yang lebih tinggi tingkatannya daerah yang bersangkutan. Dengan tetap adanya pengawasan, kebebasan itu tidak mengandung arti adanya kemerdekaan (onafhankelijk). ${ }^{8}$

Dalam hubungan kepala daerah melaksanakan penyelenggaraan pemerintahan negara memiliki dua fungsi pemerintahan. Pertama yaitu sebagai kepala daerah otonom yang memimpin penyelenggaraan dan bertanggungjawab sepenuhnya tentang jalannya pemerintahan daerah. Kedua, sebagai kepala wilayah yang memimpin

8 Philipus M. Hadjon, dkk, Pengantar Hukum Adminsitrasi Indonesia (Introduction to the Indonesian Adminstrative Law), Yogyakarta: Gajah Mada University Press, 2005, Hlm. 79-80. 
penyelenggaraan

urusan

pemerintahan umum yang menjadi tugas pemerintahan pusat di daerah. Dengan kedua fungsi tersebut kepala daerah, harus mengamankan juga program-program pemerintah di daerah, sehingga dalam pengangkatan kepala daerah dikonsultasikan kepada pemerintah pusat untuk menentukan siapa yang pantas dan memenuhi syarat sebagai Kepala Daerah. ${ }^{9}$

$$
\text { Melalui }
$$

Undang-Undang

Nomor 23 Tahun 2014 tentang Pemerintahan Daerah, beberapa urusan pemerintahan pada sektor sumberdaya alam, yang semula merupakan kewenangan pemerintah kabupaten/kota "ditarik" dan “dialihkan" menjadi kewenangan pemerintah provinsi dan pusat. Pengalihan ini dimaksudkan agar penyelenggaraan urusan pemerintahan pada sektor dimaksud jauh lebih bersih, akuntabel, efektifefisien, dan mampu memberikan jaminan bagi upaya pelestarian fungsi lingkungan dan pemanfaatan sumberdaya alam secara berkelanjutan.

\footnotetext{
${ }^{9}$ Sudono Syueb, Op.Cit. Hlm. 58.
}

Konsep dari kepemilikan dari kekayaan alam bangsa Indonesia yang berasal dari bahan tambang adalah milik seluruh rakyat Indonesia. Hal ini sesuai dengan pasal 33 ayat 3 Undang-Undang Dasar Tahun 1945. Undang-Undang Dasar Tahun 1945 Pasal 33 ayat 3 ini menyebutkan bahwa Bumi dan air dan kekayaan alam yang terkandung didalamnya dikuasai oleh Negara dan dipergunakan untuk sebesar-besarnya kemakmuran rakyat.

Dalam Undang-Undang Nomor 32 Tahun 2004 tentang Pemerintahan Daerah jo Peraturan Pemerintah Nomor 38 Tahun 2007 tentang Pembagian Urusan Pemerintahan antara Pemerintah, Pemerintah Daerah Provinsi, dan Pemerintah Daerah Kabupaten/Kota mengatakan bahwa mengenai kewenangan pemberian izin pertambangan dibagi antara pemerintah, pemerintah provinsi, dan pemerintah kabupaten/kota. Aturan tersebut lebih diperjelas lagi dengan UndangUndang Nomor 4 Tahun 2009 tentang Pertambangan Mineral dan Batu Bara, yang dalam aturan ini jelas pembagian kewenangan 
pemberian izin pertambangan. pula secara cepat mengatasi Kabupaten/kota memiliki peran yang permasalahan. Kalau otonomi besar dalam menerbitkan izin pertambangan.

Tetapi didalam UndangUndang Nomor 23 Tahun 2014 tentang Pemerintahan Daerah, kabupaten/kota tidak lagi diberi kewenangan penerbitan izin pertambangan. Penerbitan izin pertambangan yang awalnya merupakan kewenangan kabupaten/kota, sekarang menurut undang-undang ini menjadi kewenangan provinsi. Hal ini terdapat didalam pasal 14 dan 15 .

Pemberlakuan Undang-Undang Nomor 23 Tahun 2014 tentang Pemerintahan Daerah banyak mempreteli kewenangan di kabupaten. Padahal kabupaten dan kota rata-rata berkembang maju dan pesat selama Otda karena memiliki kewenangan dalam membangun daerah secara mandiri, karena orang daerah yang mengerti permasalahan di daerah dan masyarakatnya, semakin dekat rentang kendali pemerintahan disertai kewenangan akan semakin baik, sehingga kembali ke provinsi bayangkan panjangnya rentang kendali pemerintahan nantinya, harus dievaluasi ulang, asosiasi pemerintahan kabupaten dan kota seIndonesia harus memperjuangkannya kembali didukung unsur-unsur masyarakat di daerah. Dan juga masyarakat tidak setuju kewenangan ditarik oleh provinsi karena susahnya mengurus izin yang harus dilakukan di ibukota provinsi.

Berdasarkan uraian di atas, maka penulis tertarik untuk mengkaji lebih mendalam dalam bentuk tesis yang berjudul: "IMPLIKASI PERALIHAN KEWENANGAN BIDANG PERIZINAN PERTAMBANGAN UMUM DARI DAERAH KABUPATEN/KOTA KEPADA PROVINSI JAWA BARAT BERDASARKAN UNDANG-UNDANG NOMOR 23 TAHUN 2014 TENTANG PEMERINTAHAN DAERAH DIHUBUNGKAN DENGAN ASAS-ASAS UMUM pemerintah kabupaten dan kota dapat 
(STUDI KASUS DI KABAPATEN PURWAKARTA)".

\section{Identifikasi Masalah}

Berdasarkan uraian latar belakang masalah tersebut maka dapat dirumuskan permasalahan sebagai berikut :

1. Bagaimana

Implikasi

Peralihan Kewenangan

Bidang Perizinan

Pertambangan Umum Dari

Daerah Kabupaten

Purwakarta Ke Provinsi Jawa

Barat Berdasarkan UndangUndang Nomor 23 Tahun 2014 tentang Pemerintahaan Daerah?

2. Bagaimana Implikasi peralihan kewenangan dari $\mathrm{Kab} /$ Kota ke Provinsi terhadap pelayanan pertambangan umum di kabupaten Purwakarta dihubungkan dengan AsasAsas Umum Pemerintahan Yang Baik?

\section{B. HASIL DAN} PEMBAHASAN

1. Implikasi Peralihan Kewenangan Pemerintah Daerah Provinsi dalam

\section{Menerbitkan}

Izin

\section{Pertambangan}

Berdasarkan

Undang-

Undang Nomor 23 Tahun

2014 tentang Pemerintahan

Daerah

Perkembangan kegiatan pertambangan di Indonesia dalam beberapa dekade terakhir sangat membawa dampak yang sangat penting terhadap konsep pertambangan di Indonesia. Sejak reformasi pewacanaan untuk mereformasi semua ketentuan hukum pertambangan yang ada telah menjadi pandangan kritis pemerhati lingkungan sekaligus pemerintah. Secara umum politik hukum di Indonesia telah menjadi program pembangunan pemerintah, dimana politik tersebut dimulai perkembangannya sejak pergantian kekuasaan pasca reformasi.

Pada saat masih digunakannya Undang-Undang Nomor 32 Tahun 2004 Tentang Pemerintahan Daerah, yang mempunyai kewenangan dalam pengelolaan sumber daya alam tambang adalah Pemerintah Daerah. Dikarenakan sistem pemerintahan sebelum berlakunya Undang-Undang 
Nomor 32 Tahun 2004 Tentang Pemerintahan Daerah bersifat sentralistik, yang artinya segala macam urusan yang berkaitan dengan pertambangan, baik yang berkaitan dengan penetapan izin kuasa pertambangan, kontrak karya, perjanjian karya pengusahaan batubara maupun lainnya. Setelah berlakunya Undang-Undang Nomor 32 Tahun $2004 \quad$ Tentang Pemerintahan Daerah, kewenangan dalam pemberian izin diserahkan kepada pemerintah daerah (provinsi, kabupaten/kota) dan pemerintah pusat sesuai dengan kewenangannya.

Dalam pelaksanaan otonomi daerah berdasarkan Undang-Undang Nomor 32 Tahun 2004 Tentang Pemerintahan Daerah, pemerintah daerah memiliki kewenangan untuk mengelola dan memanfaatkan galian tambang bagi kesejahteraan rakyat di daerah. Dalam pasal 8 ayat (1) Undang-Undang Nomor 4 Tahun 2009 Pertambangan Mineral dan Batubara, kewenangan pengelolaan pertambangan pemerintah Kabupaten/Kota melakukan pengelolaan pertambangan mineral dan batubara menyatakan: ${ }^{10}$

(1) Kewenangan pemerintah kabupaten/kota dalam pengelolaan pertambangan mineral dan batubara, antara lain adalah:

a. Pembuatan

peraturan

perundang-

undangan daerah;

b. Pemberian Izin

Usaha

Pertambangan dan

Izin Pertambangan

Rakyat (IPR),

penyelesaian

konflik masyarakat,

dan pengawasan

usaha

pertambangan di

wilayah

kabupaten/kota

wilayah laut

sampai dengan 4

(empat) mil;

c. Pemberian Izin

Usaha

\footnotetext{
${ }^{10}$ Pasal 8 Ayat (1) Undang-Undang Nomor 4 tahun 2009 Tentang Pertambangan Mineral dan Batubara.
} 


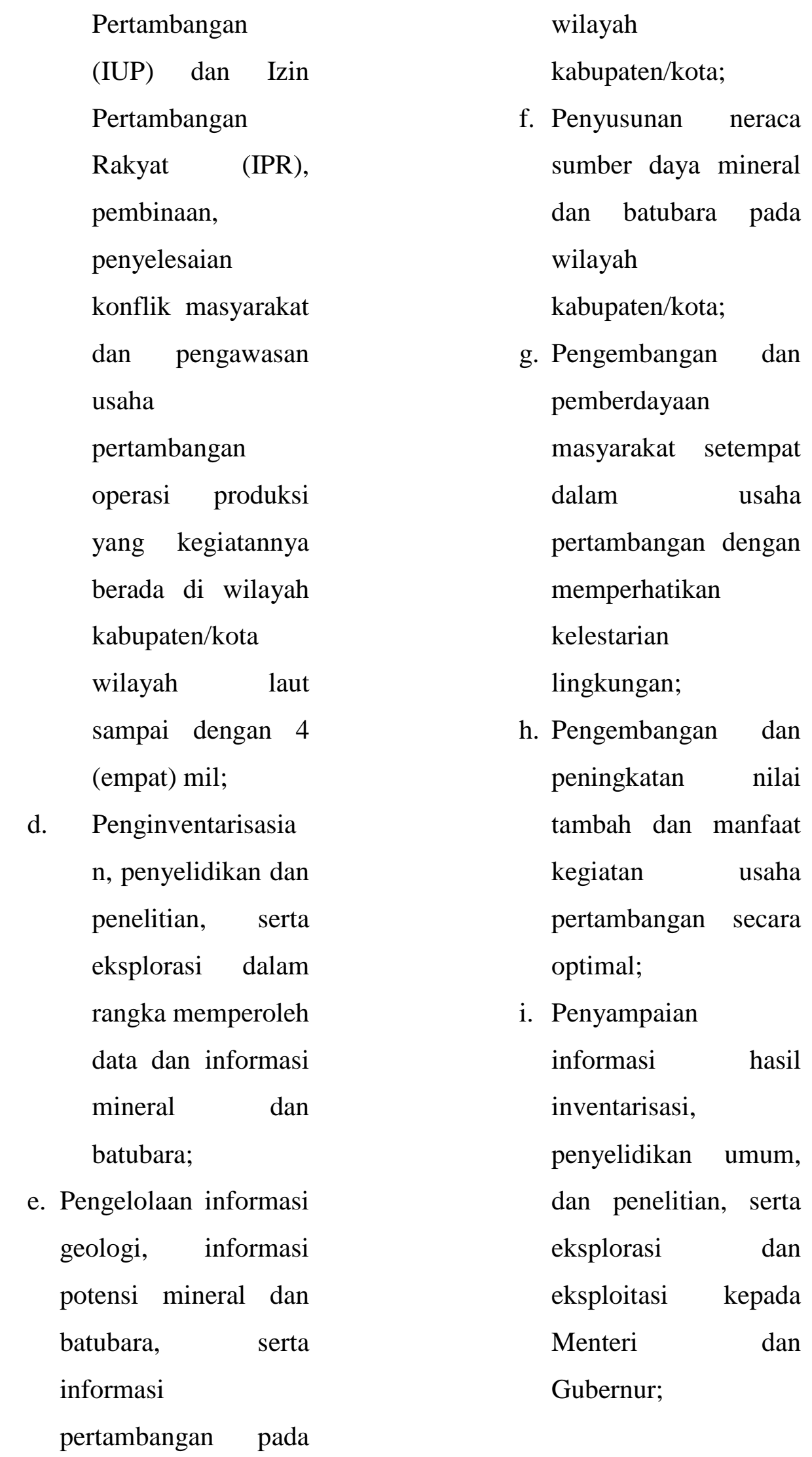


j. Penyampaian informasi hasil produksi, penjualan dalam negeri, serta ekspor kepada Menteri dan

Gubernur;

k. Pembinaan dan pengawasan terhadap reklamasi lahan pascatambang; dan

1. Peningkatan kemampuan aparatur pemerintah kabupaten/kota dalam penyelenggaraan pengelolaan usaha pertambangan.

\section{Kewenangan pemerintah} daerah dalam mengelolah sumber daya alam serta kewenangan pemberian izin juga diatur pada Undang-undang nomor 32 tahun 2004 tentang Pemerintahan Daerah tercantum dalam pasal 17 ayat (1) dan (2).

Dengan adanya kewenangan pengelolaan pertambangan tujuannya agar pengelolaan tersebut tidak selalu terpusat, sedangkan yang mengetahui keadaan dan kegiatan yang nyata adalah pemerintahan daerah. Di samping itu kewenangan tersebut juga untuk menciptakan ketertiban, keteraturan, dan kedamaian dalam pengelolaan pertambangan.

Kewenangan kabupaten/kota dilaksanakan sesuai dengan ketentuan peraturan perundangundangan yang berlaku. Walaupun pemerintah daerah diberikan kewenangan untuk pengelolaan pertambangan umum, namun semua kebijakan yang berkaitan dengan pertambangan umum masih di dominasi oleh pemerintah pusat. Seperti yang menandatangani kontrak karya pada wilayah kewenangan pemerintah kabupaten/kota adalah bupati/walikota dengan perusahaan pertambangan. Ini berarti pemerintah kabupaten/kota tidak dapat mengembangkan substansi kontrak karya sesuai dengan kebutuhan daerah. ${ }^{11}$ Dengan ini kewenangan pengelolaan sumber daya alam (pertambangan) yang meliptui perizinan, penetapan wilayah,

11 Salim HS, Hukum Pertambangan Di Indonesia, Jakarta: PT. Raja Grafindo Persada, 2005, Hlm. 52-53. 
maupun operasional dari kegiatan pertambangan merupakan kewenangan pemerintah daerah.

Seiring berjalannya waktu, izin usaha pertambangan yang dikeluarkan sering tidak melalui prosedur yang seharusnya, sehingga mengakibatkan konflik antara pemegang izin usaha pertambangan. Dimana izin yang tidak melalui prosedur yang seharusnya dapat melanggar hak izin usaha tersebut. Banyak perusahaan yang menyalahi prosedur perizinan, karena kurang ketatnya pengawasan dari pemerintah daerah dalam mengeluarkan izin dengan tidak mengindahkan dampak negatif terhadap lingkungan yang cukup besar. Oleh karena itu pemerintah menerbitkan Undang-Undang Nomor 23 Tahun $2014 \quad$ Tentang Pemerintahan Daerah, yang menjadi peraturan baru sebagai penguasaan atas sumber daya mineral serta kewenangan untuk mengeluarkan izin kegiatan pertambangan. Sesuai dengan yang tercantum pada pasal 14 ayat (1) Undang-Undang Nomor 23 Tahun 2014 Tentang Pemerintahan Daerah:

$\begin{array}{lr}\text { "Penyelenggaran } & \text { urusan } \\ \text { bidang kehutanan, kelautan, } & \\ \text { serta energi dan sumber daya } & \\ \text { mineral dibagi } & \text { antara } \\ \text { pemerintah pusat dan } & \\ \text { pemerintah provinsi". } & \end{array}$

Dengan ini pemerintah daerah tidak lagi memiliki kewenangan dalam mengeluarkan izin kegiatan pertambangan. Dengan ini masalah perizinan kehutanan dan pertambangan diatur oleh pemerintah provinsi. Sejalan dengan berlakunya Undang-Undang Nomor 23 Tahun 2014 Tentang Pemerintahan Daerah, Kementrian Energi dan Sumber Daya Manusia Republik Indonesia mengeluarkan surat edaran yang pada intinya bahwa perubahan status izin usaha pertambangan kewenangan dari sub sektor mineral dan batubara dibagi antara Pemerintah Pusat pertambangan bukan lagi milik kewenangan pemerintah daerah Kabupaten/Kota tetapi beralih menjadi kewenangan pemerintah provinsi.

Sesuai dengan dasar hukum yang melandasi otonomi daerah, pemerintah daerah boleh 
menjalankan otonomi seluas-luasnya kecuali urusan pemerintahan yang oleh undang-undang ditentukan sebagai urusan pemerintah pusat. Maksudnya, pelaksanaan kepemerintahan yang dilakukan oleh pemerintah daerah masih berpatokan pada undang-undang pemerintahan pusat. Siswanto Sunarno berpendapat bahwa konsep pemikiran tentang otonomi daerah mengandung pemaknaan terhadap eksistensi otonomi tersebut terhadap penyelenggaraan pemerintahan daerah, pemikiran-pemikiran tersebut antara lain: $^{12}$

Pemikiran pertama, bahwa prinsip otonomi daerah dengan menggunakan prinsip otonomi seluas-luasnya. Arti seluasluasnya ini mengandung makna bahwa daerah diberikan kewenangan membuat kebijakan daerah, untuk memberi pelayanan, peningkatan peran serta, prakarsa, dan pemberdayaan masyarakat yang bertujuan

${ }^{12}$ Sunarno Siswanto, Hukum Pemerintahan Daerah di Indonesia, Jakarta: Sinar Grafika, 2009, Hlm. 8 untuk peningkatan kesejahteraan rakyat.

Pemikiran kedua, bahwa prinsip otonomi daerah dengan menggunakan prinsip otonomi yang nyata dan bertanggung jawab. Prinsip otonomi nyata adalah suatu prinsip bahwa untuk menangani urusan pemerintahan dilaksanakan berdasarkan tugas, wewenang, dan kewjiban yang senyatanya telah ada, serta berpotensi untuk tumbuh, hidup dan berkembang sesuai dengan potensi dan kekhasan daerah. Dengan demikian, isi dan jenis otonomi bagi setiap daerah tidak selalu sama dengan daerah lainnya. Adapun otonomi yang bertanggung jawab adalah otonomi yang dalam penyelenggaraannya harus benar-benar sejalan dengan tujuan dan maksud pemberian otonomi, yang pada dasarnya untuk memberdayakan daerah termasuk meningkatkan kesejahteraan rakyat yang 
merupakan bagian utama dari tujuan nasional.

Seiring dengan prinsip di atas, dan tujuan serta cita-cita yang terkandung dalam undang-undang yang terkait penyelenggaraan otonomi daerah harus selalu berorientasi pada peningkatan kesejahteraan masyarakat dengan selalu memerhatikan kepentingan dan aspirasi yang tumbuh dalam masyarakat. Di samping itu, penyelenggaraan otonomi daerah juga harus menjamin keserasian hubungan antara daerah yang satu dengan daerah lainnya. Artinya, mampu membangun kerja sama antar daerah untuk meningkatkan kesejahteraan bersama dan mencegah ketimpangan antar daerah. Hal yang tidak kalah pentingnya bahwa otonomi daerah juga harus mampu menjamin hubungan yang serasi antar daerah dengan pemerintah. Artinya, harus mampu memelihara dan menjaga keutuhan wilayah negara dan tegaknya Negara Kesatuan Republik Indonesia dalam rangka mewujudkan tujuan negara.
Kedudukan negara adalah sebagai pemilik bahan galian mengatur peruntukan dan penggunaan bahan galian kemakmuran masyarakat sehingga negara menguasai bahan galian tambang. Tujuan penguasaan oleh negara (pemerintah) adalah agar kekayaan nasional tersebut dimanfaatkan untuk sebesar-besarnya kemakmuran seluruh rakyat Indonesia. Dengan demikian, baik perseorangan, masyarakat maupun pelaku usaha, sekalipun memiliki hak atas sebidang tanah di permukaan, tidak mempunyai hak menguasai ataupun memiliki bahan galian yang terkandung di bawahnya. $^{13}$

Sebagaimana diamanatkan oleh Undang-Undang Dasar Negara Kesatuan Republik Indonesia Tahun 1945, terdapat urusan pemerintahan yang sepenuhnya menjadi kewenangan Pemerintah Pusat yang dikenal dengan istilah urusan pemerintahan absolut dan ada urusan pemerintahan konkuren. Urusan pemerintahan konkuren terdiri atas urusan pemerintahan wajib dan

${ }^{13}$ Op.Cit. Salim, Hlm. 10 
urusan pemerintahan pilihan yang dibagi antara pemerintah pusat, daerah provinsi, dan daerah kabupaten/kota.

Urusan pemerintahan wajib dibagi dalam urusan pemerintahan wajib yang terkait pelayanan dasar dan urusan pemerintahan wajib yang tidak terkait pelayanan dasar. Untuk urusan pemerintahan wajib yang terkait Pelayanan Dasar ditentukan Standar Pelayanan Minimal (SPM) untuk menjamin hak-hak konstitusional masyarakat.

$$
\text { Pembagian }
$$

urusan

pemerintahan konkuren antara Daerah provinsi dengan Daerah kabupaten/kota walaupun urusan pemerintahan sama, perbedaannya akan nampak dari skala atau ruang lingkup urusan pemerintahan tersebut. Walaupun Daerah provinsi dan Daerah kabupaten/kota mempunyai urusan pemerintahan masing-masing yang sifatnya tidak hierarki, namun tetap akan terdapat hubungan antara pemerintah pusat, daerah provinsi dan daerah kabupaten/kota dalam pelaksanaannya dengan mengacu pada Norma, Standar, Prosedur dan
Kriteria (NSPK) yang dibuat oleh Pemerintah Pusat. Prinsip pembagian urusan pemerintahan konkuren yaitu akuntabilitas, efisiensi, eksternalitas dan strategis nasional.

Seperti diatur pada UndangUndang Nomor 4 Tahun 2009 Tentang Pertambangan Mineral dan Batubara, kewenangan pemerintah daerah kabupaten/kota antara lain: ${ }^{14}$

1. Menetapkan wilayah pertambangan rakyat setelah berkonsultasi dengan DPRD;

2. Memberikan rekomendasi kepada gubernur soal penerbitan IUP yang berada dalam wilayah lintas kabupaten/kota dan kepada menteri penerbitan IUP lintas provinsi;

3. Menerbitkan IUP operasi produksi untuk lokasi penambangan, lokasi pengolahan dan pemurnian serta

${ }^{14}$ Undang-Undang Nomor 4 tahun 2009 Tentang Pertambangan Mineral dan Batubara. 
pelabuhan yang berada dalam satu wilayah kabupaten/kota;

4. Memberikan rekomendasi kepada Gubernur untuk IUP lintas kabupaten/kota dan kepada menteri terkait IUP lintas provinsi;

5. Menerbitkan izin pertambangan rakyat;

6. Menerbitkan Izin Usaha Pertambangan (IUP) di wilayahnya;

7. Mencabut IUP atau Izin Usaha Pertambangan khusus (IUPK).

Dengan begitu, maka sesuai dengan skala ruang lingkup daerahnya bahan golongan tambang A dan B yang merupakan tambang yang memiliki nilai ekonomis yang tinggi, kewenangannya berada di tangan pemerintah pusat dan pemerintah provinsi, sedangkan golongan tambang $\mathrm{C}$ kewenangannya masih berada di pemerintah provinsi jika golongan tambang tersebut skala ruang lingkupnya luas dan merupakan bahan galian mineral sedangkan bahan galian golongan $\mathrm{C}$ yang skala ruang lingkupnya kecil dan bukan merupakan bahan galian non mineral serta izin pemanfaatan langsung panas bumi dalam daerah kabupaten/kota, menjadi kewenangan milik pemerintah daerah kabupaten/kota.

Dengan diberikannya kewenangan pemerintah pusat dan provinsi sebagai pemegang kewenangan mengeluarkan izin kegiatan pertambangan, maka pemerintah daerah kabupaten/kota tidak memiliki kewenangan mengeluarkan izin kegiatan pertambangan. Namun pemerintah daerah dapat mengeluarkan izin kegiatan tambang jika skala atau ruang lingkup kegiatan tambang tersebut masih di lingkup daerah atau masih dalam kabupaten/kota saja, sedangkan kegiatan pertambangan yang skala lingkupnya lebih luas atau lingkupnya dipakai di seluruh provinsi kewenangan untuk proses perizinannya harus ke pemerintah provinsi. Secara normatif, pengaturan urusan pemerintahan dimaksud sepertinya sederhana, karena hanya sekedar pengalihan 
kewenangan dalam pengurusan dan pengelolaannya.

\section{Pasal 14 Undang-Undang} Nomor 23 Tahun 2014 tentang Pemerintahan Daerah, menyatakan bahwa: Penyelenggaraan urusan pemerintahan bidang kehutanan, kelautan, serta energi dan sumber daya mineral dibagi antara pemerintah pusat dan daerah provinsi.

$$
\text { Pasal } 15 \text { Undang-Undang }
$$

Nomor 23 Tahun 2014 tentang

Pemerintahan Daerah, menyatakan bahwa: Pembagian urusan pemerintahan konkuren antara pemerintah pusat dan daerah provinsi serta daerah kabupaten/kota tercantum dalam lampiran yang merupakan bagian yang tidak terpisahkan dari undang-undang ini.

Pada lampiran Undang-Undang Nomor 23 Tahun 2014 tentang Pemerintahan Daerah mengenai pembagian urusan pemerintahan bidang energi dan sumber daya mineral terdapat pada poin cc. Pada lampiran ini terlihat bahwa daerah kabupaten/kota tidak memiliki kewenangan sama sekali dalam hal penerbitan izin pertambangan mineral dan batubara.

Setiap pejabat administrasi negara dalam bertindak (menjalankan tugas-tugasnya) harus dilandasi wewenang yang sah yang diberikan peraturan perundang-undangan. Dengan demikian setiap perbuatan para pejabat administrasi negara harus mempunyai landasan hukum. ${ }^{15}$ Oleh karena itu, setiap pejabat administrasi negara sebelum menjalankan tugasnya harus terlebih dahulu dilekati dengan suatu kewenangan yang sah berdasarkan peraturan perundangundangan. $^{16}$

Secara teoritis kewenangan yang bersumber dari peraturan perundang-undangan diperoleh melalui tiga cara yaitu, atribusi, delegasi, dan mandat. Mengenai atribusi, delegasi, dan mandat ini H.D. Van Wijk/ Willem Konijnenbelt mendefinisikan sebagai berikut: ${ }^{17}$

\footnotetext{
${ }^{15}$ Safri Nugraha, et. al., Hukum Administrasi Negara, Fakultas Hukum Universitas Indonesia, Depok: 2007, Hlm. 38.

${ }^{16} \mathrm{Ibid}$.

17 Supandi, "Kewenangan Diskresi Pemerintah Dalam Sistem Hukum Indonesia" dalam Subur MS (Editor), Peradilan Administrasi Kontemporer, Genta Press, Yogyakarta, 2014, Hlm. 24
} 
a. Atribusi adalah itu, dikaitkan dengan pendekatan pemberian wewenang penyerahan kewenangan di atas, pemerintahan oleh tentu hasil penilaian berdasarkan pembuat undang-undang berbagai kriteria yang tetap kepada organ pemerintahan.

diserahkan kepada daerah berdasarkan cara bertahap menurut

b. Delegasi adalah pelimpahan wewenang pemerintahan dari satu organ pemerintahan kepada organ pemerintahan lainnya.

c. Mandat terjadi ketika organ pemerintahan mengizinkan

kewenangannya

dijalankan oleh organ lain atas nama dirinya.

Berdasarkan hal tersebut, kewenangan yang dimiliki provinsi dalam penerbitan izin pertambangan merupakan kewenangan yang sah, karena didapat dari peraturan perundang-undangan. Penyerahan kewenangan harus memperhatikan keseimbangan antara dua orientasi: efisiensi pemerintahan dan demokrasi politik di mana pada ujungnya adalah penilaian apakah publik bisa memperoleh pelayanan yang bermutu atau sebaliknya. Selain kondisi dan kemampuan riil daerah bersangkutan.

Efisiensi pelayanan dalam penerbitan izin pertambangan akan lebih terasa apabila kewenangan penerbitan izin pertambangan berada pada kabupaten/kota. Sebab untuk pengurusan izinnya tidak perlu ke daerah provinsi yang jaraknya bisa beratus-ratus kilometer.

Kewenangan harus dikelola secara adil, jujur, dan demokratis. Cara pandang yang demikian inilah yang tepat untuk meletakkan otonomi luas dalam rangka kemandirian daerah yang mampu mengoptimalkan sumber daya lokal dalam menjawab tantangan global.

Sedikit kewenangan yang diturunkan oleh pusat kepada daerah dampaknya adalah implementasi otonomi daerah tidak berjalan sesuai dengan yang diinginkan oleh daerah. Berdasarkan tabel-tabel diatas, kewenangan pada daerah 
kabuapten/kota sangat berkurang. Padahal semakin tinggi kewenangan yang diturunkan kepada daerah, akan berpengaruh positif terhadap implementasi kebijakan otonomi daearah. ${ }^{18}$

2. Implikasi Peralihan Kewenangan Dari Kab/Kota Ke Provinsi Terhadap Pelayanan Pertambangan Umum Di Kabupaten Purwakarta

Dihubungkan Dengan Asas-Asas Umum Pemerintahan Yang Baik.

Kewenangan Pemerintah Dalam Mengeluarkan Izin kegiatan Pertambangan Penyelenggaraan pemerintahan daerah memasuki era baru yaitu dengan digantikannya Undang-Undang Nomor 32 tahun 2004 dengan Undang-Undang Nomor 23 tahun 2014 tentang Pemerintahan Daerah. Lahirnya Undang-Undang Nomor 23 tahun 2014 tentang Pemerintahan Daerah, dilatarbelakangi oleh adanya berbagai permasalahan yang timbul dari pelaksanaan Undang-Undang Nomor 32 tahun 2004 selama ini. Beberapa permasalahan yang terjadi

18 Agus Yusoff dan Andi Yusran, Desentralisasi di Indonesia, Suska Press dan Red Post Press, Pekanbaru: 2007, H1m. 29. diantaranya lemahnya fungsi gubernur dan pemerintah pusat dalam melakukan pengawasan terhadap kabupaten/kota, munculnya raja-raja kecil dengan arogansi kekuasaannya karena merasa memiliki basis politik yang kuat (dipilih oleh rakyat secara langsung). Dengan lemahnya pengawasan dan adanya arogansi kekuasaan, memunculkan berbagai kebijakan yang cenderung melanggar hukum dan melanggar asas-asas umum pemerintahan yang baik. Kondisi ini terlihat dari fakta yang ada yaitu tidak sedikit para kepala daerah terjerat dalam berbagai kasus tindak pidana korupsi dan pelanggaran hukum lainnya.

Atas dasar fakta tersebut di atas, melalui Undang-Undang Nomor 23 tahun 2014 tentang Pemerintahan Daerah, beberapa urusan pemerintahan pada sektor sumberdaya alam, yang semula merupakan kewenangan pemerintah kabupaten/kota dialihkan menjadi kewenangan pemerintah provinsi dan pusat. Pengalihan ini dimaksudkan agar penyelenggaraan urusan pemerintahan pada sektor dimaksud 
jauh lebih bersih, akuntabel, efektifefisien, dan mampu memberikan jaminan bagi upaya pelestarian fungsi lingkungan dan pemanfaatan sumberdaya alam secara berkelanjutan.

$$
\text { Kewenangan }
$$

negara merupakan kekuasaan yang diberikan oleh hukum kepada negara untuk mengurus, mengatur dan mengawasi pengelolaan bahan galian sehingga di dalam pengusahaan dan pemanfaatannya dapat meningkatkan kesejahteraan masyarakat. Kewenangan negara ini dilakukan oleh pemerintah. Penguasaan bahan galian tidak hanya menjadi monopoli pemerintah semata-mata, tetapi juga diberikan hak kepada orang dan/atau badan hukum untuk mengusahakan bahan galian sehingga hubungan hukum antara negara dengan orang atau badan hukum harus diatur sedemikian rupa agar mereka dapat mengusahakan bahan galian secara optimal. $^{19}$

$$
\text { Undang-Undang Nomor } 23
$$

Tahun 2014 Tentang Pemerintahan Daerah lebih berfokus pada

19 Salim HS, Hukum Pertambangan Di Indonesia, Jakarta: PT. Raja Grafindo Persada, 2005, Hlm. 9. organisasi pemerintahan daerah. Sebagai konsekuesnsinya, Undangundang ini mengatur berbagai hal yang berkaitan dengan aktivitas dari pemerintah daerah dalam melaksanakan tugas pokoknya sebagai suatu organisasi pemerintahan ditingkat lokal dan mempunyai hubungan dekat dengan masyarakat. Undang-Undang Nomor 23 Tahun 2014 tentang Pemerintahan Daerah ini menganut paham pembagian urusan. Antara pembagian kewenangan dengan pembagian urusan jelas terdapat pembagian yang mendasar. Secara yuridis yang diartikan dengan kewenangan adalah hak dan kekuasaan pemerintah untuk menentukan atau menggambil kebijakan dalam rangka penyelenggaraan pemerintahan sedangkan yang dimaksud dengan urusan pemerintahan adalah isi dari kewenangan itu sendiri. Undangundang ini juga menegaskan kembali kedudukan daerah otonomi sebagai bagian integral dari Negara kesatuan Indonesia. Walaupun daerah otonom merupakan badan hukum yang memiliki hak dan kewajiban mandiri, 
sebagaimana negara sebagai badan hukum, akan tetapi kedudukan (pemerintah) daerah otonom adalah melaksanakan berbagai kewenangan pemerintah yang telah didesentralisasikan oleh pemerintah pusat, dan kepemilikan kewenangan tersebut tetap berada ditangan pemerintah pusat. Sehingga secara teoritis yuridis, pemerintahan daerah merupakan sub-sistem dari sistem pemerintahan negara secara keseluruhan.

Tindakan pemerintahan harus didasarkan pada norma kewenangan menjadi dasar keabsahan atas tindak pemerintahan. Kewenangan yang diperoleh dari peraturan perundangundangan merupakan legalitas formal, artinya yang memberi legitimasi terhadap tindak pemerintahan, maka dikatakan bahwa substansi asas legalitas tersebut adalah kewenangan, yakni kewenangan yang diperoleh dari peraturan perundang-undangan. Hal ini sesuai dengan prinsip Negara hukum yang diletakkan undangundang sebagai sumber kewenangan oleh karena itu berbicara tentang dasar-dasar bersangkut paut dan tidak dapat dipisakan dengan asas legalitas.

Asas legalitas (legaliteit beginsel) merupakan salah satu prinsip utama yang di jadikan dasar penyelenggaraan pemerintahan dan negara, khususnya dalam negara hukum. Asas legalitas ini didalam hukum administrasi mengandung makna, pemerintah tunduk kepada undang-undang, dan semua ketentuan yang mengikat warga Negara harus didasarkan pada Undang-undang oleh karena itu asas legalitas sebagai landasan kewenangan pemerintah.

Kebijakan penggelolaan sumber daya alam perlu memperhatikan dan menginterasikan prinsip-prinsip: ${ }^{20}$

1. Sumber daya alam harus dimanfaatkan dan dikelolah untuk tujuan kemakmuran dan kesejahteraan rakyat secara berkelanjutan dari generasi kegenerasi.

\footnotetext{
${ }^{20}$ Nurjaya, I Nyoman, Pengelolaan Sumber Daya Alam Perspektif Antropologi Hukum, Jakarta: Prestasi Pustaka Publisher, 2008, Hlm. 113.
} 
2. Sumber daya alam harus dimanfaatkan dan dialokasikan secara adil dan demokratis dikalangan intra maupun antar generasi dan kesetaraan gender.

3. Pemanfaatan dan pengelolaan sumber daya alam harus mampu menciptakan kohevisitas masyarakat diberbagai lapisan dan kelompok serta mampu melindungi dan mempertahankan eksistensi budaya lokal, termasuk sistem hukum yang hidup dan berkembang dalam masyarakat adat/local.

4. Pengelolaan sumber daya alam harus dilakukan dengan pendekatan sistem untuk mencegah terjadinya praktekpraktek pengelolaan yang bersifat persial, egosektoral atau ego-daerah, dan tidak terkoordinasi.

5. Kebijakan dan praktikpraktik pengelolaan sumber daya alam harus bersifat spesifik lokal dan disesuaikan dengan kondisi ekosistem dan masyarakat setempat

Inti dari prinsip-prinsip tersebut, kebijakan penggelolaan sumber daya alam tidak berorientasi pada eksploitasi tetapi mengacu pada keberlanjutan fungsi sumber daya alam, tidak bercorak sentralistik tetapi bersifat desentralisasi, tidak mengedepankan pendekatan pendekatan sektoral tetapi menggunakan pendekatan holistik, memberi ruang hidup bagi kebudayaan lokal termasuk kemajemukan hukum yang secara nyata hidup dan berkembang dalam masyarakat. $^{21}$

Konsekuensi ketiadaan kewenangan pemerintah kabupaten/kota dalam perizinan pertambangan mineral dan batubara di daerah kabupaten kota menurut Undang-Undang Nomor 23 Tahun 2014 Tentang Pemerintahan Daerah Implikasi hukum yang bisa timbul dari ketiadaan kewenangan pemerintah kabupaten/kota dalam

${ }^{21}$ Ibid, Hlm. 114. 
perizinan pertambangan mineral dan batubara yaitu:

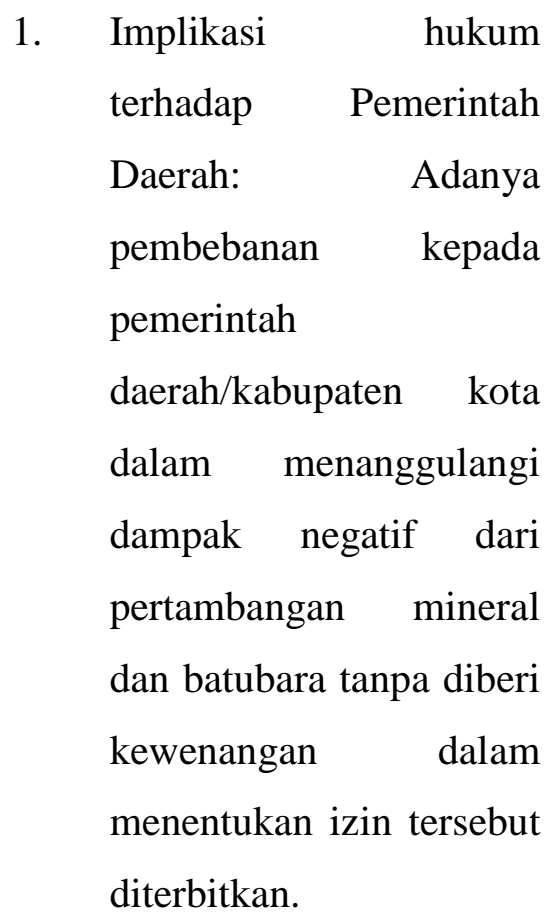

2. Implikasi terhadap Pemerintahan Daerah: Daerah kabupaten/kota pasif dalam menjalankan pemerintahannya karena tidak sesuai dengan asas desentralisasi.

3. Implikasi terhadap Lingkungan: Dengan tidak adanya kewenangan mengakibatkan bertambahnya tambang illegal dan sulit untuk pemerintah kabupaten/kota untuk ikut dalam pencegahan kerusakan ekosistem dan mengontrol diwilayah pertambangan.

Secara umum, permasalahan akibat Pertambangan Tanpa Izin selalu berkaitan dengan tiga aspek penting, yaitu:

1. Merugikan Negara, berupa kehilangan pendapatan negara dari sektor perpajakan;

2. Merusak dan mencemari lingkungan hidup antara lain dengan bentuk penggundulan hutan, erosi, dan pencemaran air sungai:dan

3. Pelecehan hukum, sebagai pencerminan dari status mereka yang beroperasi tanpa izin.

Menurut Moh. Mahfud MD cakupan otonomi sebagai berikut: ${ }^{22}$

a. Asas Otonomi Formal

\footnotetext{
${ }^{22}$ Mafhud MD, Membangun Politik Hukum, Menegakkan Konstitusi, Jakarta: Pustaka LP3ES, 2006, Hlm. 97.
} 
Dalam asas otonomi formal pembagian tugas, wewenang dan tanggung jawab antara pusat dan daerah untuk mengatur rumah tangganya sendiri tidak dirincikan di dalam undang-undang.

Pandangan yang di pakai dalam asas ini adalah bahwa tidak ada perbedaan sifat antara urusan yang diselenggarakan oleh pusat dan daerah. Pembagian tugas,wewenang dan tanggung jawab tersebut semata-mata berdasarkan atas keyakinan bahwa suatu urusan pemerintahan akan berhasil baik, jika diurus dan diatur oleh satuan pemerintahan tertentu, dan sebaliknya. Dengan demikian, asas otonomi formal memberikan keleluasaan yang luas kepada daerah untuk mengatur dan mengurus urusan pemerintahan sebagai urusan rumah tangganya sendiri, seperti yang dikatakan oleh Tresna:

"Daerah tidak boleh mengatur apa yang telah diatur dengan undangundang c.q. Peraturan Daerah yang lebih tinggi martabatnya. Apa bila pihak yang lain tinggi kemudian mengatur apa yang tadinya telah diatur oleh daerah, maka peraturan daerah yang bersangkutan sejak itu tidak berlaku lagi", ${ }^{23}$

Jadi titik berat perkiraan asas otonomi formal adalah pertimbangan daya guna hasil guna pembagian tugas, wewenang, dan tanggung jawab. $^{24}$ Tetapi ada beberapa kelemahan dalam asas otonomi formal:

23 R. Tresna, Bertamasya ke Taman Ketatanegaraan, Bandung: Dibya, tt., Hlm. 32.

${ }^{24}$ RDH Koesoemahatmadja, Pengantar ke Arah Sistem Pemerintahan Daerah di Indonesia, Bandung: Binacipta, 1978, Hlm. 15. 
1) Daya guna dan hasil guna otonomi daerah sangat tergantung pada kreatifitas dan aktivitas daerah, sehingga dalam kenyataan daerah yang tidak mampu memanfaatkan peluang akan banyak bergantung pada pusat atau tingkat daerah yang lebih tinggi. Daerah akan selalu menunggu "petunjuk" mengenai urusan-urusan pemerintahan yang semestinya diatur dan diurusnya.

2) Keleluasaan daerah belum tentu dimanfaatkan dengan baik karena adanya kemungkinan hambatan dari sudut keuangan. ${ }^{25}$ Artinya jika tidak ditopang oleh sumber keuangan yang memadai, maka otonomi formal tidak akan efektif.

3) Secara teknis daerah tidak dapat mudah mengetahui urusan-urusan yang belum

${ }^{25}$ Amrah M, Aspek-aspek Hukum Otonomi Daerah, 1903-1976, Bandung: Alumni, 1978, Hlm. 15. ditangani oleh pusat dan pemerintah daerah yang lebih tinggi. ${ }^{26}$

Dengan demikian, meskipun secara sepintas asas otonomi formal ini kelihatannya mendorong keleluasan dan menguatnya desentralisasi, tetapi dalam kenyataannya justru sering sebaliknya, yakni mendorong pada kecenderungan sentralisasi. Bagir Manan menulis tentang ini: "ketidakpastian urusan rumah tangga daerah, tidak ada tradisi otonomi, rendanya inisiatif daerah akan menjelmakan daerah yang serba menunggu dan tergantung pada pusat". 27

b. Asas Otononi Materiil Berbalikan dengan asas otonomi formal, maka asas otonomi materiil memuat. secara rinci (di dalam peraturan perundang-undangan.)

${ }^{26}$ The Liang Gie, Pertumbuhan Pemerintah Dareah di Negara Republik Indonesia, Jilid 111, Jakarta: Gunung Agung, 1968, Hlm. 62.

27 Bagir Manan, Hubungan Pusat dan Daerah Menurut Undang-Undang Dasar Negara Republik Indonesia Tahun 1945, Jakarta: Pustaka Sinar Harapan, 1994, Hlm. 28. 


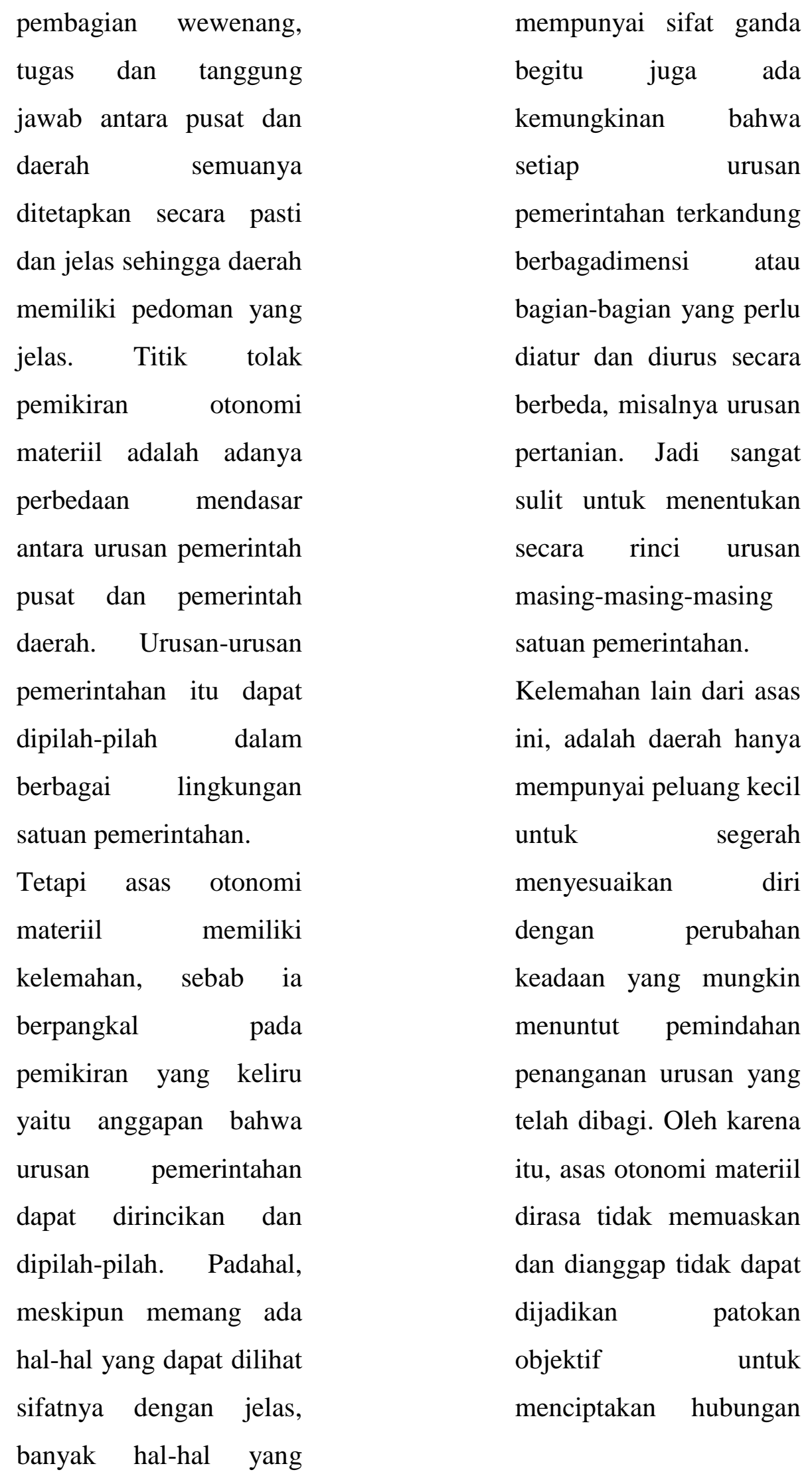


yang serasi antara pusat

dan daerah.

c. Asas Otonom Rill

Asas otonom rill merupakan jalan tengah. $^{28}$ Antara asas otonomi formal dan materiil. Dalam asas ini, penyerahan urusan kepada daerah otonom didasarkan pada foktorfaktor rill. Persoalan yang muncul adalah yang manakah yang lebih dominan atara asas formal dan asas materiil dalam asas riil. Menurut Bagir Manan dari uraian Tresna terdapat kesan bahwa sebagai jalan tenggah asas otonom rill lebih mengutamakan asas formalnya. Karena asas otonomi formal mengandung gagasan untuk mewujudkan prinsip kebebasan kemandirian bagi daerah sementara asas otonom materiil akan merangsang

${ }^{28}$ Tresna, Op.Cit., Hlm. 34. timbulnya ketidakpuasan daerah dan "spanning" hubungan antara pusat dan daerah., 29

Dalam asas riil, asas materiil berperan memberikan kepastian sejak awal mengenai urusan daerah. Melalui asas materiil, urusan pangkal diserakan dikembangkan dengan asas formal yang lebih memberi kebebasan dan kemandirian Aspek asas otonomi materiil dalam bentuk penyerahan urusan pangkal, di samping aspek sistem rumah tangga formal, menjadi salah satu ciri yang membedakan asas otonomi rill dari asas otonomi lainnya. Pada prinsipnya dengan adanya penyelenggaraan pemerintahan daerah diarahkan untuk mempercepat terwujudnya

${ }^{29}$ Bagir Manan, Op.Cit., Hlm. 33. 
kesejahteraan masyarakat

melalui peningkatan

pelayanan,

pemberdayaan, dan peran

serta masyarakat, serta

peningkatan daya saing

daerah dengan

memperhatikan prinsip

demokrasi, pemerataan,

keadilan, dan kekhasan

suatu daerah dalam

sistem Negara Kesatuan

Republik Indonesia.

Efisiensi dan efektivitas

penyelenggaraan

pemerintahan daerah

perlu ditingkatkan

dengan lebih

memperhatikan aspek-

aspek hubungan antara

Pemerintah Pusat dengan

daerah dan antar daerah,

potensi dan

keanekaragaman daerah,

serta peluang dan

tantangan persaingan

global dalam kesatuan

sistem penyelenggaraan

pemerintahan negara.

Dengan berlakunya

Undang-Undang Nomor
23 Tahun 2014

sebagaimana telah diubah

dengan Undang-Undang

Nomor 9 Tahun 2015

tentang Pemerintahan

Daerah,

mengesampingkan

kewenangan pemerintah

kabupaten/kota menurut

Pasal 8 Undang-Undang

Nomor 4 Tahun 2009

tentang pertambangan

mineral dan batubara,

maka pengaturan

kewenangan perizinan

pertambangan mineral

dan batubara pada tataran

pemerintah daerah

kabupaten/kota diambil

alih oleh pemerintah

daerah provinsi yang

merupakan wakil

pemerintah pusat.

Dapat dilihat dari konstitusi Indonesia yaitu pada Pasal 18, 18A dan 18B UUD Negara Republik Indonesia Tahun 1945. Negara mengakui dan menghormati otonomi 
daerah. Hal ini

mengakibatkan

pengaturan kewenangan

yang tidak sesuai dengan

asas desentralisasi, dan

tidak sesuai dengan

tujuan dibentuk dan

diakuinya pemerintahan

daerah oleh UUD Negara

Republik Indonesia

Tahun 1945.

Pengaturan kewenangan

penerbitan perizinan

pertambangan mineral

dan batubara seyogyanya

konsisten dengan asas

otonomi. Sehingga dapat

mempercepat

terwujudnya

kesejahteraan rakyat

melalui peningkatan

pelayanan,

pemberdayaan, peran

serta masyarakat, dan

sistem pemerintahan

daerah yang mandiri,

efektif dan efisien serta

peningkatan daya saing

daerah dengan

memperhatikan prinsip

demokrasi, keadilan, dan kekhasan suatu daerah

dalam sistem Negara

Kesatuan Republik

Indonesia.

Dihubungkan dengan Asasasas umum pemerintahan yang layak (AAUPL) menurut Jazim Hamidi: ${ }^{30}$

1. AAUPL merupakan nilai-nilai etik yang dihidup dan berkembang dalam lingkungan hukum administrasi Negara.

2. AAUPL berfungsi sebagai pegangan bagi pejabat administrasi negara dalam menjalankan fungsinya, merupakan alat uji bagi hakim administrasi dalam menilai tindakan administraasi negara (yang berwuju penetapan/beshikking), dan sebagai dasar pengajuan gugatan bagi pihak penggugat.

30 Jazim Hamidi, Penerapan Asas-Asas Umum penyelenggaraan yang layak $(A A U P B) \quad d i$ Lingkungan Peradilan Administrasi Indonesia, Bandung: Citra Adya Bakti, 1999, Hlm. 24. 
3. Sebagian besar dari

landasan ketentuan

AAUPL masih

peraturan perundang-

merupakan asas-asas

yang tidak tertulis, masih

abstrak dan dapat digali

dalam praktik kehidupan

di masyarakat.

undangan, kepatutan,

keajegan, dan keadilan

dalam setiap kebijakan

penyelenggaraan

pemerintahan.

4. Sebagian asas yang lain sudah menjadi kaidah hukum tertulis dan terpencar dalam berbagai peraturan hukum positif.

Asas-asas umum pemerintahan yang baik Menurut Pasal 10 UndangUndang Nomor 30 Tahun 2014 tentang Administrasi Pemerintahan: ${ }^{31}$

1. Asas Kepastian Hukum

Kepastian Hukum adalah asas dalam negara hukum yang mengutamakan

31 Bagian Ketiga Asas-Asas Umum Pemerintahan yang Baik, Pasal 10 ayat (1) UU No. 30 Tahun 2014 tentang Administrasi Pemerintahan menyatakan: "AUPB yang dimaksud dalam UndangUndang ini meliputi asas: a. kepastian hukum; b. kemanfaatan; c. ketidakberpihakan; d. kecermatan; e. tidak menyalahgunakan kewenangan; $\mathrm{f}$. keterbukaan; g. kepentingan umum; dan h. pelayanan yang baik". Pasal 10 ayat (2) UU No. 30 Tahun 2014 tentang Administrasi Pemerintahan menyatakan: "Asas-asas umum lainnya di luar AUPB sebagaimana dimaksud pada ayat (1) dapat diterapkan sepanjang dijadikan dasar penilaian hakim yang tertuang dalam putusan Pengadilan yang berkekuatan hukum tetap".

2. Asas Kemanfaatan Asas

Kemanfaatan adalah

manfaat yang harus

diperhatikan secara

seimbang antara:

kepentingan individu

yang satu dengan

kepentingan individu

yang lain;

kepentingan individu

dengan masyarakat; (3)

kepentingan Warga

Masyarakat

kepentingan kelompok

masyarakat yang satu dan

kepentingan kelompok masyarakat yang lain; (5) kepentingan pemerintah dengan Warga

Masyarakat;

kepentingan generasi

yang sekarang dan kepentingan generasi

mendatang; 
kepentingan manusia dan

ekosistemnya;

kepentingan pria dan

wanita.

3. Asas Ketidakberpihakan

Asas Ketidakberpihakan

adalah asas yang

mewajibkan Badan

dan/atau Pejabat

Pemerintahan dalam

menetapkan dan/atau

melakukan Keputusan

dan/atau Tindakan

dengan

mempertimbangkan

kepentingan para pihak

secara keseluruhan dan

tidak diskriminatif.

4. Asas Kecermatan

Asas Kecermatan adalah

asas yang mengandung

arti bahwa suatu

Keputusan dan/atau

Tindakan harus

didasarkan pada

informasi dan dokumen

yang lengkap untuk

mendukung legalitas

penetapan dan/atau

pelaksanaan Keputusan

dan/atau Tindakan sehingga Keputusan

dan/atauTindakan yang

bersangkutan

dipersiapkan dengan

cermat sebelum

Keputusan dan/atau

Tindakan tersebut

ditetapkan dan/atau

dilakukan.

5. Asas

Tidak

Menyalahgunakan

Kewenangan

Asas

Tidak

Menyalahgunakan

Kewenangan adalah asas

yang mewajibkan setiap

Badan dan/atau Pejabat

Pemerintahan tidak

menggunakan

kewenangannya untuk

kepentingan pribadi atau

kepentingan yang lain

dan tidak sesuai dengan

tujuan pemberian

kewenangan tersebut,

tidak melampaui, tidak

menyalahgunakan,

dan/atau tidak

mencampuradukkan

kewenangan.

6. Asas Keterbukaan 
Asas Keterbukaan adalah asas yang melayani masyarakat untuk mendapatkan akses dan memperoleh informasi yang benar, jujur, dan tidak diskriminatif dalam penyelenggaraan

pemerintahan dengan tetap memperhatikan perlindungan atas hak asasi pribadi, golongan, dan rahasia negara.

7. Asas Kepentingan Umum

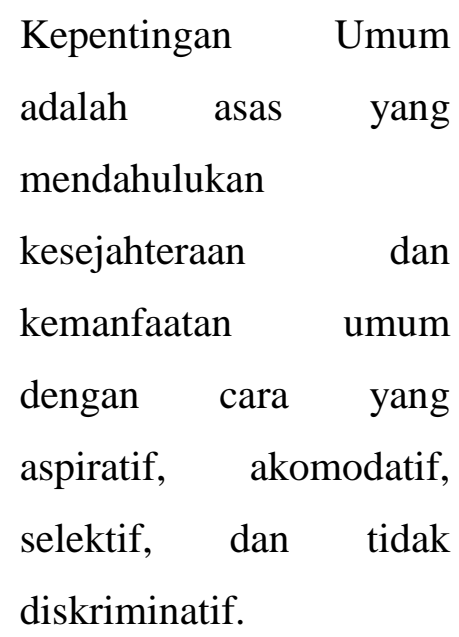

8. Asas Pelayanan yang Baik

Asas Pelayanan yang Baik adalah asas yang memberikan pelayanan yang tepat waktu, prosedur dan biaya yang jelas, sesuai dengan standar pelayanan, dan ketentuan peraturan perundang-undangan.

Dengan telah dialihkannya kewenangan bupati/walikota dalam hal pengelolaan sumberdaya alam, khususnya sebagaimana yang diatur dalam Undang-Undang Nomor 23 Tahun 2014 tentang Pemerintahan Daerah, maka bupati/walikota tidak berwenang lagi untuk menerbitkan keputusan kepala daerah terkait dengan penetapan perizinan pengelolaan sumberdaya alam dimaksud. Sedangkan terhadap keputusan perizinan yang telah dikeluarkan, berdasarkan Asas Umum Pemerintahan yang Baik (asas kepercayaan, asas kepastian hukum, asas keadilan, asas kebijakan yang memberatkan tidak boleh berlaku surut) seharusnya masih dinyatakan tetap berlaku sampai dengan berakhirnya masa izin yang diberikan.

Namun yang menjadi persoalan manakala masa izin masih berlaku cukup lama, apakah pejabat pemberi izin masih mau melakukan pengawasan atas keputusan izin yang 
telah dikeluarkan. Karena kemudahan proses pelayanan berdasarkan asas hukum administrasi (contrarius actus), pejabat pemberi izin merupakan pejabat yang berwenang untuk melakukan pengawasan dan penegakan hukum atas keputusan izin yang dikeluarkan, padahal kewenangan atas urusan pemerintahan dimaksud telah dicabut/dialihkan. Hal ini yang kiranya perlu dikoordinasikan antara pemerintah provinsi/pusat dengan pemerintah kabupaten/kota.

Sedangkan untuk perizinan baru, berdasar Surat Edaran Menteri Dalam Negeri Nomor 120/253/Sj, tanggal 16 Januari 2015 Tentang Penyelenggaraan Urusan Pemerintahan Setelah Ditetapkan Undang-Undang Nomor 23 Tahun 2014 Tentang Pemerintahan Daerah, pada angka 3 disebutkan khusus penyelenggaraan perizinan dalam bentuk pemberian atau pencabutan izin dilaksanakan oleh susunan/tingkatan pemerintahan sesuai dengan pembagian urusan pemerintahan konkuren sebagaimana dimaksud dalam Undang-Undang Nomor 23 tahun 2014 dengan mengutamakan kecepatan dan perizinan serta mempertimbangkan proses dan tahapan yang sudah dilalui. Berdasarkan surat edaran ini berarti bahwa pemerintah kabupaten/kota tidak lagi memiliki kewenangan untuk menerbitkan izin baru, karena sudah menjadi kewenangan pemerintah provinsi sesuai dengan lingkup luas kegunaan dari pertambangan tersebut, yang sesuai dengan ketentuan undangundang tentang pemerintahan daerah. Akan tetapi pemerintah daerah dapat mengeluarkan izin kegiatan tambang dengan skala lingkup kegiatan itu masih dalam batas kawasan daerah tersebut.

\section{Penutup}

Berdasarkan pemaparan dan analisis yang telah dikemukakan penulis, maka penulis menarik kesimpulan sebagai berikut:

1. Implikasi peralihan kewenangan bidang perizian pertambangan umum dari Kabupaten/Kota ke Provinsi berdasarkan Undang-Undang Nomor 
23 Tahun 2014 tentang

Pemeritahan Daerah

yaitu adanya

Pengembangan sistem

ketatanegaraan Indonesia

termasuk Pemerintahan

Daerah merupakan

kerangka dasar sistem

pengelolaan/pemanfaatan

Sumber Daya Alam yangdimiliki oleh Negara agar dapat dipergunakan untuk sebesar-besarnya kemakmuran rakyat. Konsistensi penerapan desentralisasi

kewenangan dalam rangka otonomi daerah akan lebih menjamin terpeuhinya amanah konstitusi saebagaimana tertuag dalam Pasal 33 Undang-Udang Dasar 1945. Atas dasar maka sebaiknya pemerintah lebih fokus pada fungsi regulator dalam pengelolaan sumber daya alam termasuk pengelolaan pertambangan mineral dan batubara.

2. Implikasi kewenangan dari Kabupaten/Kota ke provinsi terhadap kewenangan pelayanan $\mathrm{p}$ [ertambangan umum di kabupaten purwakarta dihubbungkan dengan Asas-asas umum pemerintahan yang baik yaitu adanya Implikasi Akibat Peralihan Kewenangan Dari Kab/Kota Ke Provinsi terhadap kegiatan pertambangan setelah berlakunya UndangUndang Nomor 23 Tahun 2014 tentang Pemerintahan Daerah, maka Bupati/Walikota tidak berwenang lagi untuk menerbitkan Keputusan Kepala Daerah terkait dengan penetapan perizinan pengelolaan sumberdaya alam. Sedangkan terhadap keputusan perizinan yang telah 
dikeluarkan, berdasarkan

Asas

Umum

Pemerintahan yang Baik

(asas kepercayaan, asas

kepastian hukum, asas

keadilan, asas kebijakan

yang memberatkan tidak

boleh berlaku surut)

seharusnya masih

dinyatakan tetap berlaku

sampai dengan

berakhirnya masa izin

yang diberikan.

\section{Saran}

1. Pemerintah Daerah dalam hal ini melalui

Badan Lingkungan

Hidup hendaknya lebih

selektif

dalam

mengeluarkan

izin

lingkungan

bagi

penanggung jawab usaha

industri, harus bisa

memberikan penekanan

bagi penangung jawab

usaha

untuk

memperhatikan peraturan

yang berlaku, dan disertai

dengan sanksi-sanksi

yang tegas dan dapat memberikan efek jera

terhadap penanggung

jawab usaha yang

melakukan pelanggaran

dan pengrusakan

lingkungan hidup.

2. Pengawasan hendaknya

dilakukan oleh BLH

secara aktif, tidak hanya

menunggu aduan dari

masyarakat, sehingga

bisa mencegah tejadinya

permasalahan lingkungan

serta BLH secara

insidentil melakukan

sidak (inspeksi

mendadak) ke

perusahaan-perusahan

baik skala besar maupun

kecil agar lebih peka

terhadap pengelolaan

lingkungan hidup.

\section{Daftar Pustaka}

Buku:

Ade Saptono, Hukum dan Kearifan Lokal Revitalisasi Hukum Adat Nusantara, Jakarta: PT. Grasindo, 2010. 
Inu Kencana Syafei, Sistem Pemerintahan Indonesia, Jakarta: Rineka Cipta, 2002.

Jimly Asshiddiqie, Konstitusi dan Konstitusionalisme

Indonesia, Jakarta: Sinar Grafika, 2010.

Deddy Supriady Bratakusumah dan

Dadang Solihin, Otonomi Penyelenggaraan

Pemerintahan Daerah, Jakarta: PT. Gramedia Pustaka Utama, 2002.

M. Hadjon, dkk, Pengantar Hukum Adminsitrasi Indonesia (Introduction to the Indonesian Adminstrative Law), Yogyakarta: Gajah Mada University Press, 2005. Salim HS, Hukum Pertambangan Di Indonesia, Jakarta: PT. Raja Grafindo Persada, 2005.

Sunarno Siswanto, Hukum Pemerintahan Daerah di Indonesia, Jakarta: Sinar Grafika, 2009.

Safri Nugraha, et. al., Hukum Administrasi Negara, Fakultas Hukum Universitas Indonesia, Depok: 2007.
Supandi, "Kewenangan Diskresi Pemerintah Dalam Sistem Hukum Indonesia" dalam Subur MS (Editor), Peradilan Administrasi Kontemporer, Genta Press, Yogyakarta, 2014.

Agus Yusoff dan Andi Yusran, Desentralisasi di Indonesia, Suska Press dan Red Post Press, Pekanbaru: 2007.

HS, Hukum Pertambangan Di Indonesia, Jakarta: PT. Raja Grafindo Persada, 2005. Nurjaya, I Nyoman, Pengelolaan Sumber Daya Alam Perspektif Antropologi Hukum, Jakarta: Prestasi Pustaka Publisher, 2008.

Mafhud MD, Membangun Politik Hukum, Menegakkan Konstitusi, Jakarta: Pustaka LP3ES, 2006.

R. Tresna, Bertamasya ke Taman Ketatanegaraan, Bandung: Dibya, tt.

RDH Koesoemahatmadja, Pengantar ke Arah Sistem Pemerintahan Daerah di Indonesia, Bandung: Binacipta, 1978. 
Bambang Widiya Atmoko, Implikasi Peralihan Kewenangan Bidang Perizinan...

Amrah M, Aspek-aspek Hukum

Otonomi Daerah, 1903-1976,

Bandung: Alumni, 1978.

The Liang Gie, Pertumbuhan

Pemerintah Dareah di

Negara Republik Indonesia,

Jilid 111, Jakarta: Gunung Agung, 1968.

Bagir Manan, Hubungan Pusat dan

Daerah Menurut Undang-

Undang Dasar Negara

Republik Indonesia Tahun

1945, Jakarta: Pustaka Sinar

Harapan, 1994.

Jazim Hamidi, Penerapan Asas-Asas

Umum penyelenggaraan yang layak (AAUPB) di

Lingkungan Peradilan

Administrasi Indonesia,

Bandung: Citra Adya Bakti, 1999, Hlm. 24.

\section{Peraturan Perundang-undangan}

Undang-Undang Dasar Negara

Republik Indonesia Tahun

1945, Pustaka Agung

Harapan. Surabaya.

Undang-Undang No. 23 Tahun 2014

tentang Pemerintahan

Daerah.

Undang-Undang Nomor 4 tahun 2009 Tentang Pertambangan

Mineral dan Batubara. 